\title{
PENERAPAN METODE EKSPOSITORI DALAM MENINGKATKAN PRESTASI BELAJAR IPA
}

\author{
Nurhayati \\ SD Negeri 3 Macorawalie \\ Jalan Poros Pangkajene Kecamatan Pancarijang Kabupaten Sidenreng Rappang \\ la.detapa@gmail.com
}

\begin{abstract}
Abstrak: Penerapan Metode Ekspositori dalam Meningkatkan Prestasi Belajar IPA. Penelitian ini merupakan penelitian tindakan kelas yang dilakukan pada siswa kelas IV SDN 3 Macorawalie. Tujuan yang ingin dicapai adalah membuktikan bahwa dengan menerapkan metode ekspositori dapat meningkatkan prestasi belajar IPA. Pengumpulan data dilakukan melalui tes tertulis, observasi langsung, dan wawancara. Penelitian ini dilaksanakan dalam dua siklus. Hasil penelitian menunjukkan bahwa nilai rata-rata kondisi awal sebesar 4,8; pada siklus I meningkat menjadi 5,7; dan pada siklus II menjadi 6,7. Dengan demikian, disimpulkan bahwa penerapan metode ekspositori dapat meningkatkan prestasi belajar IPA pada siswa kelas IV SDN 3 Macorawalie.
\end{abstract}

Kata kunci: metode ekspositori, pembelajaran, prestasi belajar

\begin{abstract}
The Application of the Expository Method in Improving Science Learning Achievement. This research is a classroom action research conducted on fourth grade students of SDN 3 Macorawalie. The goal to be achieved is to prove that applying the expository method can improve science learning achievement. Data was collected through written tests, direct observation, and interviews. This research was conducted in two cycles. The results showed that the average value of the initial conditions was 4.8 ; in the first cycle increased to 5.7; and in the second cycle increased to 6.7. Thus, the application of expository can improve science learning achievement in fourth grade students of SDN 3 Macorawalie.
\end{abstract}

Keywords: expository method, learning, learning achievement

Metode ekspositori ini akan menjadi efektif dan efisien yang dapat menyebabkan siswa belajar secara bermakna, bila dipergunakan sebagaimana mestinya sesuai dengan situasi dan kondisi (Sumanto, 2006). Metode ekspositori merupakan metode campuran dari metode ceramah, metode tanya jawab, metode demonstrasi dan metode pemberian tugas.

Kegiatan pembelajaran diarahkan untuk memberdayakan semua potensi peserta didik untuk menguasai kompetensi yang diharapkan. Kegiatan pembelajaran mengembangkan kemampuan untuk mengetahui, memahami, melakukan sesuatu, hidup dalam kebersamaan dan mengaktualisasikan diri, dengan demikian kegiatan perlu : 1) berpusat pada peserta didik; 2). mengembangkan pada kreativitas pesrta didik; 2) menciptakan kondisi yang menyenangkan dan menatang; 4) bermuatan nilai, etika, estetika, lofgika, dan kinestika; 5) menyediakan pengalaman belajar yang beragam (Depdiknas, 2004).

Dulu, bagi siswa pelajaran IPA merupakan pelajaran hafalan yang tidak memerlukan pemikiran yang mendalam, sehingga dalam pelajaran IPA guru hanya menggunakan metode ceramah. Sementara pelajaran IPA adalah pelajaran yang sangat 
penting, mengambilnya membutuhkan presentasi dan latihan. Dalam kasus seperti itu, hasil belajar siswa pada pelajaran IPA rendah karena guru masih menggunakan metode pembelajaran yang terbatas dan tidak ada layanan pendukung, sehingga menyulitkan siswa untuk memahami pelajaran yang diberikan (Ririantika et al., 2020; Lamalla et al., 2019; Kamalia et al., 2020; Fajarwati \& Budianto, 2020).

Untuk mengajar siswa lebih baik, guru harus mau menggali lebih dalam potensi diri mereka sendiri. Dalam mengajar khususnya, guru perlu meningkatkan pengajarannya. Dia harus mampu beradaptasi dengan metode pengajaran yang terbarukan. Dalam menjalankan tugasnya sehari-hari, tentunya guru selalu mengharapkan keberhasilan dalam mengajar. Siswa diharapkan dapat menerima, mengingat, mengingat, dan menghasilkan semua pengetahuan, keterampilan, dan kemampuan yang disajikan (Soekartawi, 1996; Bell, 1986; Hasibuan, 1995).

Di dalam proses belajar mengajar siswa merupakan sasaran yang mendapat pengajaran yang sesuai dengan tujuan pendidikan. Maka dalam proses belajar mengajar siswa harus aktif dalam melaksanakan belajar dibawah bimbingan guru. Dalam seluruh kegiatan mengajar komponen metode mempunyai peranan sangat penting, tanpa metode yang tepet seluruh proses dan pemahaman belajar kurang berhasil. Jadi metode mengajar yang baik dan tepat sangat berperan dalam proses belajar mengajar.

Oleh karena itu, perlu dikembangkan metode belajar yang sesuai dengan hakekat IPA misalnya metode ekspositori. Metode ekspositori adalah merupakan metode campuran dari metode ceramah, tanya jawab, demonstrasi, dan penugasan. Metode ini dinilai lebih praktis dan mudah dilaksanakan.

Beberapa permasalahan yang berkaitan dengan usaha peningkatan prestasi belajar IPA telah diungkapkan di depan, maka masalah-masalah tersebut dapat diidentifikasikan sebagai berikut.

1. Metode yang digunakan oleh guru dalam pelajaran IPA kurang bervariasi.

2. Tingkat kesulitan siswa dalam memahami materi pelajaran.
Dari beberapa identifikasi masalah tersebut dirumuskan batasan permasalahan, yakni apakah ada peningkatan prestasi belajar IPA siswa kelas IV dengan menggunakan metode ekspositori?

\section{METODE}

Penelitian ini dilakukan di kelas IV SD Negeri 3 Macorawalie, Kecamatan Pancarijang mata pelajaran Ilmu Pengetahuan Alam (tahun 2019). Subyek penelitian adalah siswa kelas IV sebanyak 22 orang dan guru kelas IV. Penelitian ini mengikuti alur penelitian tindakan kelas yang terdiri dari siklus. Setiap siklus meliputi kegiatan perencanaan, pelaksanaan tindakan, pengamatan, dan refleksi (Arikunto, 2006). Data dikumpulkan melalui teknik tes, observasi, dan wawancara. Hasil tes dianalisis secara kuantitatif dalam bentuk nilai rata-rata. Sedangkan hasil observasi dan wawancara dianalisis secara kualitatif.

\section{HASIL DAN PEMBAHASAN}

\section{Hasil Penelitian \\ Deskripsi Kondisi Awal}

Berawal dari latar belakang masalah yang ada peneliti melaksanakan penelitian yang dimulai dari perencanaan, pelaksanaan tindakan, pengamatan, dan refleksi mengungkapkan bahwa pembelajaran IPA pada siswa kelas IV SD Negeri 3 Macorawalie tahun 2019 khususnya semester I prestasi belajarnya masih rendah.

Proses pembelajaran IPA pada siswa kelas IV SD Negeri 3 Macorawalie tahun 2019, guru masih menggunakan metode ceramah padahal diharapkan dalam pembelajaran IPA kelas IV menggunakan metode ekspositori yaitu perpaduan antara metode ceramah, metode demostrasi, metode tanya jawab, dan metode pemberian tugas, sehingga dapat meningkatkan prestasi belajar siswa dalam pelajaraan IPA khususnya pokok bahasan perpindahan panas.

Dari permasalahan yang ada, maka peneliti melakukan penelitian tindakan kelas dengan menerapkan metode ekspositori untuk meningkatkan prestasi belajar siswa kelas IV dalam dua siklus. Hasil evaluasi belajar siswa kelas IV dalam pelajaran IPA sebelum 
dilakukan tindakan dapat dilihat pada tabel berikut ini:

Tabel 1 Hasil Nilai Evaluasi Belajar Kondisi Awal

\begin{tabular}{cccc}
\hline No. & Nilai & Frekuensi & Keterangan \\
\hline 1. & 2 & 6 anak & Rendah \\
\hline 2. & 4 & 5 anak & Rendah \\
\hline 3. & 5 & 6 anak & Rendah \\
\hline 4. & 6 & 2 anak & Sedang \\
\hline 5. & 7 & 1 anak & Sedang \\
\hline 6. & 8 & 1 anak & Tinggi \\
\hline 7. & 9 & 1 anak & Tinggi \\
\hline & Jumlah & 22 anak & Rata-rata $: 4,8$
\end{tabular}

Sumber data: hasil tes

Berdasarkan tabel diatas, ternyata nilai yang dicapai paling banyak adalah nilai antara $2-5$ berarti masih rendah, dengan nilai rata-rata 4,8

\section{Deskripsi Hasil Siklus I}

1. Perencanaan Tindakan

Dalam siklus ini mempersiapkan rencana sebagai berikut :

a. Membuat rencana pembelajaran dan alat evaluasi pelajaran IPA kelas IV dengan pokok bahasan Perpindahan Panas.

b. Mempersiapkan alat peraga berupa KIT PANAS

c. Mempersiapkan bahan-bahan berupa: air, kacang hijau, mentega, potongan kertas, kertas karbon, kertas grenjeng.

d. Membuat lembar observasi sebagai alat pengamatan.

e. Meminta bantuan seorang rekan guru IPA sebagai observator

Langkah- langkah pembelajaran

a. Mengawali dengan mengucapkan salam dan berdoa bersama

b. Menyuruh siswa untuk membuka buku paket IPA pada pokok bahasan perpindahan panas.

c. Memberi motivasi dan apresiasi

d. Membacakan tujuan pembelajaran yang tertera pada rencana pembelajaran pada siklus I.

e. Menjelaskan pengertian energi panas

f. Menjelaskan tentang perpindahan panas g. Menjelaskan macam-macam perpindahan panas

h. Mendemonstrasikan perpindahan panas baik secara konveksi, konduksi, dan radiasi

i. Memperkenalkan alat peraga yang digunakan beserta nama-namanya.

j. Memberi kesempatan siswa untuk bertanya

k. Membuat kelompok untuk melakukan eksperimen tiap kelompok 8 anak

1. Menyuruh siswa untuk menulis hasil eksperimen dan menyimpulkan hasil eksperimen pada lembar observasi

m. Mengadakan evaluasi materi dengan tes tertulis pilihan ganda dan langsung dicocokkan

n. Memberikan tugas untuk dikerjakan dirumah soal-soal tentang perpindahan panas

o. Menutup pelajaran

2. Pelaksanaan Tindakan

Langkah-langkah pembelajaran sebagai berikut :

a. Guru mengawali pembelajaran dengan memberi salam, kemudian melakukan presentasi siswa yang mengikuti pelajaran.

b. Guru memotivasi siswa dengan pertanyaan apa yang kamu ketahui tentang energi panas dan perpindahan panas.

c. Guru menunjuk siswa untuk menjawab pertanyaan itu guna membangkitkan semangat belajar.

d. Siswa yang ditunjuk oleh guru dapat menjawab pertanyaan mengenai perpindahan panas walaupun belum sempurna.

e. Guru memperkenalkan alat peraga dan bahan yang akan digunakan untuk praktek IPA perpindahan panas secara konduksi.

f. Guru membentuk kelompok kerja tiap kelompok terdiri dari 8 anak. 
g. Guru mendemonstrasikan tentang perpindahan panas secara konduksi, konveksi, dan radiasi siswa memperhatikan penjelasan guru, tapi ada siswa yang tidak memperhatikan.

h. Guru memberi teguran kepada siswa yang tidak memperhatikan tadi dengan pertanyaan.

i. Guru melanjutkan penjelasan dan demonstrasinya tentang perpindahan panas cara kerja dan langkah praktek.

j. Guru membuat tabel pengamatan untuk diisi siswa sesuai dengan praktek yang diamati.

k. Guru membagi alat peraga dan bahan kepada siswa yang akan akan digunakan dalam percobaan.

1. Guru menjelaskan perpindahan panas ada tiga cara yaitu : konduksi, konveksi, dan radiasi.

m. Guru menyuruh siswa untuk mengumpulkan lembar kerja yang telah diisi oleh siswa pada akhir eksperimen dan menyimpulkan hasil eksperimen.

n. Guru memberi tugas untuk dikerjakan dirumah.

o. Guru mengadakan evaluasi berupa tes tertulis pilihan ganda dan langsung dicocokan.

p. Guru mengarahkan untuk mengerjakan PR dan belajar sungguh-sungguh.

q. Guru menutup pelajaran dengan mengucap salam.

3. Hasil Pengamatan Siklus I

a. Melalui tes tertulis

Berdasarkan evaluasi yang telah dilaksanakan terhadap pelaksanaan siklus I diperoleh hasil nilai sebagai berikut :

Tabel 2 Hasil Tes Tertulis Siklus I

\begin{tabular}{cccc}
\hline No. & Nilai & Frekuensi & Keterangan \\
\hline 1. & 2 & 2 anak & Rendah \\
\hline 2. & 4 & 2 anak & Rendah \\
\hline 3. & 5 & 6 anak & Rendah \\
\hline 4. & 6 & 5 anak & Sedang \\
\hline 5. & 7 & 2 anak & Sedang \\
\hline 6. & 8 & 2 anak & Tinggi \\
\hline 7. & 9 & 2 anak & Tinggi \\
\hline & Jumlah & 22 anak & Rata-rata $: 5,7$
\end{tabular}

Sumber data: hasil tes
Berdasarkan tabel 2 dapat dilihat bahwa ada peningkatan prestasi belajar dari kondisi awal yang masih rendah ke siklus I $(4,8$ menjadi 5,7$)$.

b. Observasi

Ternyata pada hasil observasi siklus I ditemukan bahwa ada 2 siswa yang bertanya, ada 2 siswa yang tidak memperhatikan pelajaran, ada 18 siswa yang tidak bertanya, semua siswa mengerjakan evaluasi

4. Refleksi

Berdasarkan hasil observasi dapat diambil analisa data siklus I penelitian tindakan kelas masih ada kekurangan dalam kegiatan belajar mengajar. Hasil ini dapat dilihat dari nilai rata-rata evaluasi IPA pada kondisi awal adalah 4,8 sedangkan nilai ratarata evaluasi IPA pada siklus I adalah 5,7. Kesimpulan refleksi adalah sudah peningkatan dalam prestasi belajar IPA siswa kelas IV tetapi karena soal berupa pilihan ganda dan kelompok kerja terdiri dari 8 anak maka siswa masih kurang menguasai materi dan banyak siswa yang pasif dalam percobaan. Sehingga perlu untuk dilanjutkan pada siklus II.

\section{Deskripsi Hasil Siklus II}

1. Perencanaan Tindakan

Dalam siklus II mempersiapkan rencana sebagai berikut.

a. Membuat rencana pembelajaran dan alat evaluasi pelajaran IPA kelas IV dengan pokok bahasan perpindahan panas.

b. Mempersiapkan alat dan bahan yang akan digunakan dikelas

Langkah-langkah pembelajaran

a. Mulai pelajaran dengan salam

b. Memeriksa buku pelajaran untuk mengetahui siswa yang tidak membawa buku pelajaran.

c. Menyuruh siswa untuk mengumpulkan tugas PR dan memberi hukuman bagi siswa yang tidak mengerjakan.

d. Menunjuk siswa secara acak untuk ditanya jawab supaya ingat pelajaran yang lalu.

e. Memberitahu siswa bahwa hari ini akan praktek perpindahan panas secara radiasi. 
f. Menyuruh siswa untuk membuka buku paket IPA mengenai perpindahan panas.

g. Menjelaskan lagi macam-macam perpindahan panas

h. Memberi kesempatan siswa untuk bertanya

i. Membentuk kelompok praktek tiap kelompok terdiri dari 4 anak

j. Membagikan alat dan bahan yang akan digunakan pada tiap kelompok.

k. Memdemonstrasikan perpindahan panas secara radiasi

1. Menyuruh siswa untuk melakukan eksperimen sendiri dengan alat peraga.

m. Menyuruh siswa untuk menulis hasil eksperimen dan kesimpulan pada lembar kerja yang telah disediakan.

n. Memberi tugas untuk dikerjakan dirumah.

o. Mengadakan evaluasi dan diawasi dengan ketat.

p. Menutup pelajaran

2. Pelaksanaan Tindakan

Langkah-langkah

sebagai berikut :

a. Guru mengawali pembelajaran dengan memberi salam dan dilanjutkan presensi siswa yang mengikuti pelajaran semuanya masuk.

b. Guru menyuruh siswa untuk mengeluarkan buku paket IPA ternyata semua membawa.

c. Guru menyuruh siswa mengumpukan PR ternyata semua mengerjakan, setelah itu membahas PR secara singkat.

d. Guru melakukan tanya jawab pelajaran yang lalu dengan menunjuk siswa secara berurutan.

e. Guru menuliskan pelajaran dipapan tulis mengenai perpindahan panas secara radiasi disertai penjelasannya.

f. Guru menyuruh siswa untuk membentuk kelompok yang terdiridari 4 anak

g. Guru membagikan alat dan bahan yang akan digunakan dalam praktek. h. Guru menjelaskan dan mendemonstrasikan mengenai perpindahan panas secara radiasi. Alat dan bahan sama seperti pada siklus I

i. Guru memberi kesempatan pada siswa untuk bertanya

j. Guru membagikan lembar kerja dan tabel yang harus diisi setelah selesai percobaan.

k. Guru menyuruh siswa untuk mempraktekkan melalui percobaan yang sudah disiapkan.

1. Guru memantau dan mengawasi selama siswa melakukan percobaan agar siswa dapat aktif semuanya.

m. Guru memberi tugas PR

n. Guru memberi evaluasi berupa tes tertulis pilihan ganda dan uraian, diawasi dengan sungguh-sungguh.

o. Guru mencocokkan evaluasi secara langsung.

p. Guru memberikan penekanan untuk mengerjakan PR dengan sungguhsungguh.

q. Guru menutup pelajaran

3. Hasil Pengamatan Siklus II

a. Melalui tes tertulis

Berdasarkan evaluasi yang dilaksanakan terhadap pelaksanaan siklus II diperoleh hasil nilai sebagai berikut :

Tabel 3 Hasil Tes Siklus II

\begin{tabular}{cccc}
\hline No. & Nilai & Frekuensi & Keterangan \\
\hline 1. & 2 & - & - \\
\hline 2. & 4 & - & - \\
\hline 3. & 5 & 2 & Rendah \\
\hline 4. & 6 & 7 & Sedang \\
\hline 5. & 7 & 6 & Sedang \\
\hline 6. & 8 & 4 & Tinggi \\
\hline 7. & 9 & 2 & Tinggi \\
\hline \multicolumn{5}{c}{ Jumlah } & 22 anak & Rata-rata $: 6,7$ \\
\hline
\end{tabular}

Sumber data: hasil tes

b. Observasi

Ternyata dari hasil observasi siklus

II ditemukan bahwa ada 4 siswa yang bertanya, ada 1 siswa yang tidak memperhatikan pelajaran, semua siswa mengerjakan evaluasi, semua siswa aktif melaksanakan percobaan 


\section{Refleksi}

Berdasarkan hasil analisa data siklus II dalam penelitian tindakan kelas kegiatan belajar mengajar sudah ada peningkatan baik guru maupun siswanya. Hasil prestasi belajar ini dapat dilihat dari nilai rata-rata kondisi awal adalah 4,8 , nilai rata-rata siklus I menjadi 5,7, nilai rata-rata siklus II menjadi 6,7. Dari hasil ini dapat disimpulkan bahwa sudah ada peningkatan prestasi belajar IPA siswa kelas IV pada kondisi awal, siklus I, dan siklus II tetapi dari siklus I ke siklus II nilai rata-ratanya meningkat sedikit karena soal agak sulit berupa pilihan ganda dan uraian. Kalau ditinjau dari keaktifan siswa sudah lebih banyak yang aktif karena kelompok kerjanya terdiri dari 4 anak jadi semua siswa dapat aktif melakukan percobaan.

\section{Pembahasan Tiap Siklus dan Antar Siklus}

1. Pembahasan Siklus I

Berdasarkan data yang diperoleh dari penelitian tindakan kelas siklus I (mulai dari perencanaan, pelaksanaan tindakan, pengamatan, dan refleksi) ditemukan bahwa prestasi belajar IPA siswa kelas IV belum maksimal. Siswa mengalami kesulitan sehingga hanya sebagian siswa saja yang mencapai ketuntasan. Dari 22 siswa hanya dua siswa yang mendapat nilai sembilan, dua siswa mendapat nilai delapan, tiga siswa mendapat nilai tujuh, lima siswa mendapat nilai enam, enam siswa mendapat nilai lima, dua siswa mendapat nilai empat, tiga siswa mendapat nilai tiga. Berdasarkan kenyataan ini ternyata pelaksanaan pembelajaran IPA belum memuaskan, karena guru belum sepenuhnya menerapkan metode pembelajaran ekspositori dalam membuat soal evaluasi berupa pilihan ganda dan dalam pembagian kelompok kerja terlalu banyak siswa tiap kelompok 8 siswa jadi masih banyak siswa yang tidak aktif dalam percobaan.

\section{Pembahasan Siklus II}

Berdasarkan data-data yang diperoleh dari penelitian tindakan kelas pada siklus II ternyata prestasi belajar IPA siswa kelas IV ada peningkatan, karena metode pembelajaran ekspositori sudah diterapkan secara kongkrit dengan memberikan soal evaluasi pilihan ganda dan uraian serta dalam pembagian kelompok kerja tiap kelompok 4 siswa, jadi semua siswa dapat aktif melakukan percobaan dan menguasai materi. Dari 22 siswa ada tiga siswa mendapat nilai sembilan, empat siswa mendapat nilai delapan, enam siswa mendapat nilai tujuh, tujuh siswa mendapat nilai enam, dan tiga siswa mendapat nilai lima. Berdasarkan kenyataan ini pelaksanaan pembelajaran siklus II dengan menerapkan metode ekspositori secara kongkrit dapat meningkatkan prestasi belajar siswa kelas IV dalam pelajaran IPA dengan hasil nilai yang memuaskan.

2. Pembahasan Antar Siklus

Berdasarkan data pada saat belum diadakan tindakan kelas kondisi awal banyak siswa yang mendapatkan nilai rendah itu dapat dilihat dari hasil nilai evaluasi rataratanya 4,8 . Setelah diadakan tindakan pada siklus I ada peningkatan prestasi belajar IPA dengan nilai rata-rata 5,7. Kemudian tindakan ini dilakukan perbaikan dan penyempurnaan metode pada siklus II ada peningkatan lagi dengan nilai rata-rata 6,7. Keadaan seperti ini kami diskusikan dengan teman sejawat/ kolabulator, ternyata pada siklus I soal evaluasi masih berupa pilihan ganda dan kelompok kerja jumlah siswanya terlalu banyak yaitu 8 anak, sehingga masih banyak siswa yang pasif dan tidak aktif dalam percobaan. Sedangkan pada siklus II kami perbaiki dalam membuat soal evaluasi berupa pilihan ganda dan uraian serta kelompok kerjanya terdiri dari 4 anak saja agar siswa dapat aktif dalam percobaan. Siswa dapat lebih menguasai materi sehingga dapat meningkatkan prestasi belajar dalam pembelajaran IPA.

Berdasarkan penelitian tindakan kelas dan hasil tes kondisi awal, siklus I, dan siklus II ternyata dapat disimpulkan bahwa dengan menerapkan metode ekspositori secara kongkrit pada pembelajaran IPA dapat meningkatkan prestasi belajar siswa kelas IV SD Negeri 3 Macorawalie dalam pejaran IPA 


\section{DAFTAR PUSTAKA}

Arikunto, Suharsimi. 2006. Penelitian Tindakan Kelas. Jakarta: Bumi Aksara.

Bell, Gredl. 1986. Optimalisasi Media Pembelajaran. Jakarta : Gramedia Widiasarana Indonesia.

Departemen Pendidikan Nasional, Kerangka Dasar Kurikulum 2004, Jakarta: Puskur.

Fajarwati, N., \& Budianto. (2020). Peranan Metode Ekspositori Terhadap Kemampuan Belajar IPA Anak Tunagrahita Ringan. Jurnal Pendidikan Khusus, 15(1). https://jurnalmahasiswa.unesa.ac.id/in dex.php/jurnal-pendidikankhusus/article/view/35386.

Hasibuan, Moedjiono. 1995. Proses Belajar Mengajar. Bandung: Remadja Rosdakarya.

Kamalia, K., Rasyid, R. E., Zain, S., \& Kasman, N. (2020). Pengaruh Film
Pendek Terhadap Kemampuan Menulis Cerpen Siswa Kelas X SMA Negeri 2 Pangsid. Cakrawala Indonesia, 5(1), 7-9.

https://jurnal.umsrappang.ac.id/cakra wala/article/view/333

Lamalla, B., Hanafi, M., \& Ecca, S. (2019). Pengaruh Penggunaan Aplikasi Sparkol Videoscribe Terhadap Kemampuan Menyimak Siswa. 5151(2), 9-12.

Ririantika, R., M, U., Aswadi, A., \& Sakkir, G. (2020). Penerapan Model Pembelajaran Tipe "Make A Match" Terhadap Hasil Belajar Bahasa Indonesia. Cakrawala Indonesia, 5(1), $1-6$.

Soekartawi. 1996. Meningkatkan Efektifitas Mengajar. Jakarta:: Pustaka Jaya.

Sumanto. 1999. Strategi Belajar Mengajar. Surakarta : UNS press. 